\title{
SUCCESSFUL TWIN PREGNANCY AFTER ORTHOTOPIC LIVER TRANSPLANTATION
}

\author{
Júlio Cezar Uili COELHO, Mônica Beatriz PAROLIN e \\ Jorge E. Fouto MATIAS
}

\begin{abstract}
Aim - Report of a case of successful twin pregnancy following liver transplantation. Patient and Method - A 42 year-old nulliparous-woman was subjected to an orthotopic liver transplantation due to Budd-Chiari syndrome. Sixteen months after the transplantation, an ultrasonography revealed twin pregnancy. Her prenatal course was uneventful, except for mild arterial hypertension. The immunosuppressive agents used during pregnancy were cyclosporine and prednisone. Result - The patient gave birth to two healthy girls at 37 weeks of gestation. The patient's postpartum course was uneventful with normal liver and renal function tests. Conclusion - Following successful pregnancy, women may become pregnant and give birth to normal children, including twins
\end{abstract}

HEADINGS - Liver transplantation. Pregnancy, multiple. Hepatic vein thrombosis. Liver disease.

\section{INTRODUCTION}

Following successful liver transplantation, menstrual cycles return to normal in a few months and pregnancy may ensue $^{(4)}$. The first successful pregnancy in a liver transplant patient was reported by WALCOTT et al. ${ }^{(9)}$, in 1978. After the first report of twin pregnancy in a liver transplantation patient by GROW et al. ${ }^{(5)}$ in 1991, only a few of such cases have been described ${ }^{(2,6)}$.

Our objective is to present a patient who had an uneventful pregnancy and delivered normal twins.

\section{CASE REPORT}

A 42-year-old woman presented with ascites, hepatoesplenomegaly, and progressive liver failure. An ecoDoppler ultrasonography showed thrombosis of the hepatic veins due to essential thrombocytosis (Budd-Chiari syndrome). One year later, she was subjected to a successful orthotopic liver transplantation. The patient was maintained on a daily regimen of $425 \mathrm{mg}$ of cyclosporine, $5 \mathrm{mg}$ of prednisone, $100 \mathrm{mg}$ of azathioprine, and $100 \mathrm{mg}$ of aspirin. Liver function tests and hemogram were normal, except for severe thrombocytosis (platelets of 1,5 million per $\mathrm{mm}^{3}$ ). A $500 \mathrm{mg}$ of hydroxyurea was administered orally every second day during the first month until platelet count decreased to normal limits. Normal menstrual cycles was observed (restored) 3 months later. Afterwards, the patient had good recovery with no further complications.

She had no previous pregnancy and was advised not to became pregnant by using condom. However, 16 months after the transplantation, she presented amenorrhea and an ultrasonography revealed twin pregnancy. The patient's prenatal course was uneventful, except for mild arterial hypertension. Azathioprine and hydroxyurea were discontinued and prednisone, cyclosporine, and aspirin were maintained on the antepartum dosages throughout pregnancy, delivery, and postpartum periods. Hepatic tests and serum creatinine remained normal. Monitoring of serum level of cyclosporine remained within normal limits $(100-150 \mathrm{mg} / \mathrm{L})$. At 37 weeks of gestation, an ultrasonography showed areas of placenta infarction and therefore it was decided to interrupt

${ }^{1}$ Department of Surgery and Gynecology and Obstetrics of the Federal University of Parana, Curitiba, PR, Brazil.

Address for correspondence: Dr. Júlio Coelho - Rua Bento Viana, 1140 - apt. 2202 - 80240-110 - Curitiba, PR, Brazil. 
the pregnancy. The patient gave birth by cesarean section to two healthy girls of 2,290 $\mathrm{g}$ and 1,870 g. The 1- and 5-minute Apgar scores of both babies were 9 . They had no detected congenital anomalies and presented normal growth at 5 months after the birth. The patient's postpartum course was uneventful with normal liver and renal function tests.

\section{DISCUSSION}

The number of pregnancies following liver transplantation is increasing due to a better patient and graft survival and quality of life ${ }^{(7,8,10)}$. Few cases of twin pregnancy have been reported in liver transplant recipients ${ }^{(2,5,6)}$. Although pregnancy after liver transplantation does not seem to have deleterious effects on allograft function or survival, several complications both to the mother and infant have been reported ${ }^{(1,3,7)}$. Immunosuppressive agents used may cause arterial hypertension, preeclampsia, and renal dysfunction. These agents cross the placenta and may cause fetal growth retardation ${ }^{(7)}$. The rates of preterm $(40 \%$ to $86 \%)$ and cesarean $(45 \%$ to $71 \%$ ) are high $^{(1)}$

It is advisable to wait at least 2 years after liver transplantation before seeking conception ${ }^{(7)}$. Although our patient was a 44 year-old nulliparous, she became pregnant 16 months after the transplantation. She had no complications, except for mild arterial hypertension. She developed no evidence of acute or chronic hepatic rejection and no evidence of recurrent Budd-Chiari syndrome during the pregnancy or post-partum convalescence. The infants had neither congenital malformations nor infection and had normal growth to date.

Coelho JCU, Parolin MB, Matias JEF. Gravidez gemelar com sucesso após transplante hepático. Arq Gastroenterol 2002;39(4):246-247.

RESUMO - Objetivo - Descrição de um caso de gravidez gemelar com sucesso após transplante hepático. Paciente e Método - Paciente nulípara de 42 anos de idade com síndrome de Budd-Chiari foi submetida a transplante hepático. Dezesseis meses após o transplante, uma ultra-sonografia revelou gravidez gemelar. As avaliações pré-natais foram normais, exceto por apresentar hipertensão arterial leve. Os imunossupressores utilizados durante a gravidez foram ciclosporina e prednisona. Resultado - Cesariana foi realizada na $37^{\mathrm{a}}$ semana de gravidez, com nascimento de duas meninas sadias. A evolução pós-cesárea foi normal, com os exames de avaliação hepática e renal normais. Conclusão - Após o transplante hepático com sucesso, as mulheres podem engravidar e ter filhos normais, inclusive gêmeos.

DESCRITORES - Transplante de fígado. Gravidez múltipla. Trombose da veia hepática. Hepatopatias.

\section{REFERENCES}

1. Carr DB, Larson AM, Schmucker BC, Brateng DA, Carithers RL, Easterling TR Maternal hemodynamics and pregnancy outcome in women with prior orthotopic liver transplantation. Liver Transpl 2000;6:213-21.

2. Case AM, Weissman A, Sermer M, Greenblatt EM. Successful twin pregnancy in a dual-transplant couple resulting from in-vitro fertilization and intracytoplasmic sperm injection: case report. Hum Reprod 2000;15:626-8.

3. Casele HL, Laifer SA. Association of pregnancy complications and choice of immunosuppressant in liver transplant patients. Transplantation 1998;65:581-3

4. Cundy TF, O'Grady JG, Williams R. Recovery of menstruation and pregnancy after liver transplantation. Gut 1990;31:337-8.

5. Grow DR, Simon NV, Liss J, Delp WT. Twin pregnancy after orthotopic live transplantation, with exacerbation of chronic graft rejection. Am J Perinatol $1991 ; 8: 135-8$
6. Kreuzpaintner G, Ringe B, Niesert S, Pichlmayr R, Strohmeyer G. Twin pregnancy after liver transplantation. Dtsch Med Wochenschr 1990;115:895-8.

7. Molmenti EP, Jain AB, Marino N, Rishi NK, Dvorchik I, Marsh W. Liver transplantation and pregnancy. Clin Liver Dis 1999;3:163-74.

8. Radomski JS, Moritz MJ, Muñoz SJ, Cater JR, Jarrell BE, Armenti VT. Nationa transplantation pregnancy registry: analysis of pregnancy outcomes in female liver transplant recipients. Liver Transpl Surg 1995;1:281-4.

9. Walcott WO, Derick DE, Jolley JJ, Snyder DL. Successful pregnancy in a liver transplant patient. Am J Obstet Gynecol 1978;132:340-1.

10. Wu A, Nashan B, Messner U, Schmidt HH, Guenther HH, Niesert S, Pichmayr R. Outcome of 22 successful pregnancies after liver transplantation. Clin Transplant 1998;12:454-64.
Recebido em 20/8/2001 Aprovado em 20/12/2001. 